DOI: https://doi.org/10.15688/jvolsu4.2017.1.5

UDC 94(470)“1611”:323.1

Submitted: 19.10 .2016

LBC 63.3(2)44-4

Accepted: 16.01 .2017

\title{
THE ROLE OF THE PATRIARCH HERMOGENES WRITTEN APPLICATIONS IN ORGANIZATION OF ZEMSTVO MILITIA, $1611^{1}$
}

\author{
Nataliya V. Rybalko \\ Volgograd State University, Volgograd, Russian Federation \\ Evgeniya G. Dmitrieva \\ Volgograd State University, Volgograd, Russian Federation \\ Elena S. Maleeva \\ Vienna University of Applied Sciences, Vienna, Austria
}

\begin{abstract}
The article deals with a controversial issue in historical science about what specific role played by the Patriarch Hermogenes in the organization of the zemstvo movement during the Interregnum, at the beginning of the folding of the national militia at the end of December 1610 - January 1611.

Researchers have repeatedly addressed this issue, since the first half of the XIX century, offering his vision and interpretation of information from sources, but so far the question of the existence of the patriarch of letters remains open.

Unlike many conflicting evidence of narrative sources, the County assembly material correspondence deposited in the archive Solikamsk, gives us a ton more information. Analyzing the correspondence, we can trace what information and documents the city received sequentially from Nizhny Novgorod and then to the North and Siberia, as the correspondence was in XVI - XVII century in Muscovy. The correspondence contains the only mention of the patriarch of the charters, but in any document, we do not find even a brief retelling of their content, as was the case with other documents, which came on the ground during this period. Moreover, there are specific indications that the first two letters of the district from Smolensk and Moscow residents actually called "letters of i the patriarch." Comparison of evidence leads us to date the letter from Smolensk time drawing no earlier than December 29, 1610 and to refute the assumption of its of fake origin.

Thus, Hermogenes, obviously, did not write letters on his behalf, but called for a protest against the PolishLithuanian interventionists in public speeches, personal contacts with fiduciaries messengers and sent the first two letters of initiative.

Key words: the history of Russia, the Time of Troubles, 17 century, national movement, acts, Patriarch Hermogenes.

УДК 94(470)“1611”:323.1

Дата поступления статьи: 19.10.2016

ББК 63.3(2)44-4

Дата принятия статьи: 16.01.2017

\section{РОЛЬ ГРАМОТ ПАТРИАРХА ГЕРМОГЕНА В ОРГАНИЗАЦИИ ЗЕМСКОГО ОПОЛЧЕНИЯ 1611 ГОДА ${ }^{1}$}

Наталия Владимировна Рыбалко

Волгоградский государственный университет, г. Волгоград, Российская Федерация 


\section{Евгения Геннадьевна Дмитриева}

Волгоградский государственный университет, г. Волгоград, Российская Федерация

\section{Елена Сергеевна Малеева}

Венский университет прикладных наук, г. Вена, Австрия

Аннотация. В статье рассматривается дискуссионный в исторической науке вопрос о том, какую роль сыграли грамоты патриарха Гермогена в организации земского движения периода Междуцарствия, в начале складывания народного ополчения в конце декабря 1610 - январе 1611 года.

С первой половины ХІХ в. исследователи неоднократно обращались к этой проблеме, предлагая свое видение ситуации и интерпретацию источников, однако до сих пор вопрос о существовании грамот патриарха остается открытым.

В отличие от многочисленных противоречивых свидетельств повествовательных источников, более точные сведения нам дает актовый материал земской переписки, отложившейся в Соликамском архиве.

Анализируя переписку, мы можем проследить, какую информацию и какие грамоты получали города, начиная с Нижнего Новгорода (один из главных центров организации ополчения) и далее на Север и в Сибирь. В переписке содержатся только упоминания о грамотах патриарха, но ни в одном документе мы не находим даже краткого пересказа их содержания, как это происходило с остальными получаемыми на местах документами в этот период. Кроме того, есть конкретные указания на то, что «грамотами патриарха» в действительности названы две первые окружные грамоты из-под Смоленска и московских жителей. Сопоставление фактических свидетельств дает нам основание считать, что грамота из-под Смоленска была составлена не ранее, чем 29 декабря 1610 г., и опровергнуть предположение о ее подложном происхождении. Таким образом, Гермоген, очевидно, не писал грамоты, а переслал первые две инициативные грамоты от своего имени.

Ключевые слова: история России, Смутное время, XVII век, Междуцарствие, подмосковное ополчение, грамоты, патриарх Гермоген.

17 (27) февраля 2017 г. исполняется 405 лет со дня мученической смерти выдающегося деятеля эпохи Смуты патриарха Гермогена (Ермогена - церк.) - личности, несомненно, значимой не только для Русской Православной Церкви [6], но и для всей истории Российского государства. Особо отмечается его роль в событиях конца 1610 - начала 1611 г., связанных с подъемом земского движения в защиту православной веры и России от польско-литовских интервентов.

В исторической литературе XIX-XX вв. неоднократно подчеркивалось значение духовного подвига Гермогена, а также отмечалось, что на начальном этапе периода Междуцарствия «во главе временного правительства, которому подчинялись тогда люди, отшатнувшиеся от Владислава, формально признавался патриарх» [19, с. 161]. Однако до сих пор нерешенным остается вопрос о том, писал ли грамоты Гермоген в период конца 1610 первой половины 1611 г. и, как следствие, его ли управленческие действия и призывы стали главным движущим началом в деле создания Подмосковного ополчения?
Поиск инициативных грамот Гермогена, начатый исследователями во второй четверти XIX в., продолжается и сегодня. Сформировались противоположные суждения: одни ученые верят в то, что грамоты патриарха с призывом собирать первое ополчение были (например, С.Ф. Платонов [18, с. 459], В.И. Корецкий [12], В.Г. Вовина-Лебедева [4], Я.Г. Солодкин [23, с. 190], Д.М. Володихин [5], Б.Н. Флоря [26]), другие доказывают, что грамот не было (Л.М. Сухотин [24]), к борьбе патриарх призывать не мог (Скрынников [21, с. 291-332])) и роль Гермогена в деле создания первого ополчения сильно преувеличена (П.О. Горбачев [7]).

Историки основательно изучили комплекс повествовательных источников, свидетельствующих о том, что еще современники расходились во взглядах на возможность существования грамот патриарха к ополчению. О том, что грамоты были, упоминается в сочинениях польских (С. Маскевича, С. Жолкевского) и русских (С.И. Шаховского) авторов, в Столярове хронографе. О том, что патриарх Гермоген грамоты не писал, свидетель- 
ствуют Арсений Елассонский, И. Хворостинин, автор «Новой повести о преславном Российском царстве» и составитель «Нового летописца». Бо́льшая часть сочинений, повествующих о конкретном участии Гермогена в организации земского движения, отдалена по времени или географически, информация приведена в пересказе третьих лиц, что снижает фактор ее достоверности. На наш взгляд, доверие могут вызывать сочинения лиц, находившихся поблизости от Гермогена, таких как Арсений Елассонский [9]. Однако главные аргументы, по мнению Л.М. Сухотина, следует искать в «первоисточниках»-грамотах переписки городов и польских известиях $[24$, c. 335$]$.

Рассмотрим аргументы «за» и «против» существования грамот Гермогена первому ополчению, основываясь на земской переписке, отложившейся в Соликамском архиве, и польских документальных свидетельствах, известных к настоящему времени.

3a: в Актах Археографической экспедиции под № 169 (т. 2) значатся «Два воззвания патриарха Ермогена ко всему русскому народу...», датированные при публикации январем 1611 года [3, № 169, с. 286-291]. Содержание одной из этих грамот подробно пересказал в статье о Нижнем Новгороде П.И. МельниковПечерский, добавив от себя уточнение о том, что эту грамоту патриарха в начале 1611 г. «получили в Нижнем из Москвы», в ней «патриарх жаловался на мятежников, хотящих передать Россию полякам» [14]. Правда, историк высказал некоторое недоумение, почему в грамоте не говорится ни слова о Владиславе. Это было первое обращение к грамотам Гермогена периода ополчений.

Против: отнесение грамот Гермогена П.И. Мельниковым ко времени начала сбора ополчений оказалось ошибочным. Уже С.М. Coловьев, спустя 22 года после их публикации, приурочил упомянутые грамоты к восстанию против Василия Шуйского 17 февраля 1609 г., сопровождавшемуся отъездом московских людей в лагерь к Лжедмитрию II [22, с. 568]. Основание для этого есть: в первой грамоте указан адресат - московские люди, к «ложноминому... царику приставши», и указано время, когда событие произошло: «восстание в субботу сыропустную» (перед началом Вели- кого поста). Во второй же грамоте говорится, что слово пишется «не ко всем людям, а к тем, которые отъехали.., изменив царю, государю и великому князю Василию Ивановичу...» [3, № 169, с. 286-291]. Однако Пасха в 1609 г. была 16 апреля [27, с. 57], соответственно «сырная суббота» накануне начала Великого поста - 25 февраля. В этот день было восстание, а патриарх писал грамоты после 25 февраля 1609 года. Н.Ф. Дробленкова и В.Г. Вовина-Лебедева, тем не менее, склонны датировать эти два воззвания временем после 11 июля 1610 г. - после «беззаконного сведения с престола царя В.И. Шуйского» $[10 ; 4]$.

3a: сообщение о грамотах патриарха и его устных выступлениях о том, что королевич не крестится в православную веру, литовские люди «не выйдут из московские земли», «королевич нам не государь» содержатся в известной грамоте «от находившихся в осаде смолян» в пересказе со ссылкой на грамоту Ф. Андронова и М. Салтыкова, присланную под Смоленск с описанием происходившего в Москве [3, № 176 (II), с. 299-301; 24, с. 326]. Время получения послания Ф. Анронова указано в тексте грамоты из-под Смоленска: «после Рождества Христова, на пятой неделе, в субботу». Если «пятую неделю» отсчитывать от Рождества Христова (25 декабря), то получаем субботу, 26 января. Но этого не может быть, так как 27 января 1611 г. данная грамота уже была доставлена в Нижний Новгород [3, № 176, с. 297]. Если отсчитать пятую неделю от начала месяца, то, в соответствии с реконструированным нами календарем 1610 г., первое декабря приходилось на субботу (первая неделя), соответственно, суббота пятой недели - это 29 декабря, день после Рождества. Значит, грамота от Ф. Андронова и М. Салтыкова из Москвы была получена в Смоленске 29 декабря. В связи с этим, стоит усомниться в справедливости высказанного С.Ф. Платоновым (вслед за Арцыбашевым) предположения о том, что грамота является подделкой, «которая вышла не из-под Смоленска, а из какого-то политического кружка московских патриотов» [19, с. 158]. Все остальные приведенные С.Ф. Платоновым «нестыковки» соотнесения дат и событий при данной датировке снимаются. 
С С.Ф. Платоновым не был согласен и Л.М. Сухотин [24, с. 327], правда, у исследователя не хватило аргументации.

Против: нет повода для сомнений в том, что устные выступления были, но если патриарх и писал грамоты до Рождества Христова, то они точно не были известны ни в Нижнем Новгороде, ни в других городах северовостока страны, где разворачивалось земское движение, так как текстов грамот в земской переписке нет и нижегородским посланникам в начале января патриарх никакого письменного документа не дал.

3a: нижегородцы в увещательной грамоте в Вологду писали, что П. Ляпунов в грамоте, полученной в Нижнем 27 января 1611 г., сообщил им о том, что собирается со всеми городами по благословению патриарха Гермогена выступать к Москве [3, № 176, с. $297-$ $298 ; 24$, с. $235 ; 26$, с. $331-332]$.

Против: 1) грамота, полученная нижегородцами 27 января, не сохранилась, а во второй грамоте П. Ляпунова в Нижний Новгород, доставленной в Нижний 31 января и пересылавшейся далее в списках, упоминаний о грамотах Гермогена или благословении патриарха земского движения на юге России нет [3, № 176 (II), c. 299-302; 24, с. 330]. Нет этого и в других известных грамотах П. Ляпунова. В то же время и сегодня мнения на этот счет расходятся. Р.Г. Скрынников отрицал возможный факт написания Гермогеном грамот ни П. Ляпунову, ни кому-то еще «и даже на словах не призывал к оружию и кровопролитию» [21, с. 310-315]. П.О. Горбачев пришел к заключению, что П. Ляпунову, а не патриарху Гермогену принадлежала первостепенная заслуга в организации земского движения в южных уездах государства [7, с. 192-193]. В то время как Д.М. Володихин, напротив, отстаивает позицию, согласно которой Гермоген первые грамоты в десятых числах декабря отправил на юг - тушинскому воинству, а на север отправить не успел, «так как двор его разграбили» [5, с. 218-219];

2) на основании анализа документов реконструированного архива Я. Сапеги И.О. Тюменцев сделал заключение, что крушению планов возведения на русский престол королевича Владислава и началу движения первого земского ополчения способствовали дей- ствия сапежинцев [25, с. 144]. В сохранившихся грамотах и отписках властей Калуги и соседних Заокских и Северских городов нет ни одного упоминания ни о грамотах Гермогена, ни о действиях самого патриарха.

За и против: в той же грамоте нижегородцев к вологжанам говорится о двух грамотах, полученных от Гермогена с призывом «сбираться к Москве»: от московских людей и из-под Смоленска [3, № 176 (I, II), с. 298301]. То есть Гермоген прислал грамоты, но написаны они были не от его имени.

3a: в отписке ярославцев к вологжанам (после 16 февраля 1611 г.) приводится последовательный пересказ событий начиная с августа 1610 г., перечислены действия: с Москвы святейший Ермоген, патриарх и московские люди писали на Рязань «и во все украинные городы и в понизовые», с Рязани П. Ляпунов писал в Нижний, с Нижнего - в Вологду [3, № 179 , с. $304-307 ; 24$, с. 326$]$.

Против: можно говорить о начале складывания стереотипа на основе краткого пересказа, обобщения и упрощения информации, который и стал транслироваться дальше. Вполне объяснимо ее искажение: по представлениям нижегородцев, рязанцы, как и нижегородцы, должны были действовать с благословения патриарха, тем более что во второй сохранившейся грамоте рязанцы упоминают о ситуации с патриархом в Москве. Эта концепция получила распространение в дальнейшем в земской переписке. В то же время анализ психологической мотивации действий земства показал, что «призыв к защите православной веры и Московского государства стал главным лейтмотивом земского движения», а «духовные мотивы выступили объединяющим началом» [20, с. 18$]$.

3a: упоминание о грамотах патриарха есть в листе игумена Соловецкого монастыря Антония шведскому королю Карлусу: «...писал с Москвы Ермоген в В. Новгород, Псков, Казань, Н. Новгород, на Вологду, в Ярославль, в Северские города, Рязань и во все города» $[3$, № 180 , с. $308 ; 24$, с. 326$]$. То есть перечислены фактически все первые города, в которые действительно рассылались грамоты.

Против: каждый перечень пересылаемых списков грамот начинается с двух глав- 
ных инициативных документов: грамоты изпод Смоленска и грамоты московских жителей, которые нижегородцы получили от Гермогена. Грамот, составленных от имени Гермогена, в северных и сибирских городах не было. По указаниям в земской переписке можно отследить путь продвижения «комплекта» грамот: в Пермь доставлены 9 марта 1611 г. из Устюга Великого, 10 марта «пермичи» отписали об этом в Соликамск и приложили списки со всех дошедших до них грамот [15 ${ }^{2}$. Тот же перечень документов имеет грамота из Перми верхотурским воеводам от 13 марта 1611 года [16]. О грамотах Гермогена в этих отписках отдельно не говорится, как и о нем самом.

3a: 13 марта 1611 г. земские власти из Перми написали отписку патриарху Гермогену, в которой говорится, что 9 марта 1611 г. приехал к ним в Чердынь с Устюга Великого посыльщик Иванко Игошев, «привез с собой с Устюга Великого и Устюжского уезда от земских судей и старост и целовальников отписку, а под отпиской подклеены список с твоей, святейшего Ермогена, патриарха московского всея Русии, с грамоты да с отписок списки из-под Смоленска, из Нижнего Новгорода, из Рязани, с вологодских, ярославских и суздальских, а написано, чтоб нам всем... единодушно стояти за православную христианскую веру» $[17]^{3}$.

Против: «грамотой Гермогена» здесь названа грамота московских жителей - она также пересылалась, но в данном перечне отсутствует. Это отметил и Сухотин [24, c. 330-331]. Можно было бы предположить, что грамота от московских людей и есть грамота Гермогена, при том что отправитель в этой грамоте не указан, однако Гермоген упоминается как третье лицо.

3a: свидетельства гетмана А. Госевского и польско-литовских послов московским царским послам при переговорах в конце ноября 1615 года. В посольском послании говорится о грамоте, которую патриарх писал «до Просовецкого и Михаила Черкашенина» в январе (на месте года и числа пробелы) - «читаем пред вами лист с печатью его» [2, № 209, c. 471-491]. «А днем перед тем... 8 января писал тайно в городы и отослал с Василиев Чертовым в Нижний Новгород грамоту смут- ную, а из Нижнего розсылано в Кострому, Галич и иные городы» [2, № 209, с. 482]. Второй раз цитируется грамота уже с указанием числа -8 января - в третьем листе-ответе польских послов. В доказательство послы ссылаются на грамоты из переписки городов, на подлинность почерка в этих грамотах и печатей $[2$, № 210 , с. $493 ; 18$, с. $459 ; 26$, с. $325-$ 326]. Отсюда многие исследователи датируют две грамоты Гермогена 8 и 9 января 1611 года [4; 10]. В то же время не ясно, называют ли послы дату по старому или новому стилю (Л.М. Сухотин придерживался второго варианта и исходил из даты 29 декабря [24, c. 328]). Хотя если грамоту читали, то наверняка прочитали и указанную в ней дату.

Против: 1) послы Московского государства отвечали польско-литовским в 1615 г.: «патриарх так не писывал, а печать от него... взял и писал что хотел... наместник гетманский с русскими людьми, кои господарю прямили» [2, № 210, с. 493]. Л.М. Сухотин, сославшись на посольскую книгу, отметил, что печать патриарха находилась в Посольском приказе, где в то время «сидел один из главных изменников дьяк И.Т. Грамотин [24, c. 328-329];

2) нижегородцы ходили к патриарху и грамот не получили, вернувшись 12 января [3, № 176 (II), с. 199-302; 21, с. 313]. Между Нижним и Москвой было 3 дня пути, значит, нижегородцы с сыном боярским Романом Пахомовым и посадским человеком Родионом Моисеевым выехали из Москвы 9 или 10 января, но грамот не получили, так как «писать у Патриарха было некому» [3, № 176 (II), c. 199-302]. Гермоген доверительно относился к указанным людям, которые не раз у него бывали: в грамоте от конца августа 1611 г. патриарх назвал их «бесстрашными людьми» (Родион Моисеев - «свияжанин») и рекомендовал именно с ними отправить грамоты из городов в полки под Москву о непризнании царем «Маринкина сына» [3, № 194 (II), с. 333334 (в книге ошибочно с. 243-244)]. Следовательно, если бы грамота была составлена патриархом или 29 декабря, или 8 января, то он об этом обязательно бы упомянул при встрече с посланниками;

3) имеется несоответствие дат в сообщениях польских источников: так, Маскевич 
указал, что грамота Гермогена была перехвачена 15 декабря (цит. по: [24, с. 329]);

4) наличие даты в грамоте патриарха представляется нам крайне сомнительным: формуляр агитационных воззваний, бытовавших в то время в земской среде, как и грамот земской переписки, чаще не содержит дат конечного протокола, а включает только упоминание в тексте документа дат получения грамот. Ближайшие по времени из сохранившихся грамоты Гермогена (февраль 1609 г. [3, № 169, с. 286-291] и август 1611 г. [3, № 194 (II), № 194 (II), с. 333-334 (в книге ошибочно c. 243-244)]) также не содержат дат их составления.

3a: 2 письма поляка Я. Задзика, отправленных из лагеря под Смоленском своему «патрону». 1) 8 января н.ст. 1611 г. сообщается о публичном заявлении патриарха после смерти Лжедмитрия II: «легко теперь этих поганых разбойников истребить можем, когда у нас согласие будет и один только в земле неприятель»; 2) в конце января 1611 г. сообщается: «патриарх взбунтовал людей» и «отпали Нижний Новгород и Рязань» (цит. по: [26, c. 325]). Б.Н. Флоря предположил, что «взбунтовать» можно было, посылая «своих гонцов или свои грамоты», а, следовательно, утверждение А. Госевского правдиво [26, с. 325].

Против: 1) прямого упоминания о грамотах патриарха в письме поляка Я. Задзика нет;

2) совпадение дат -8 января - или не связано, или связь иная: если в грамоте патриарха была дата 8 января, то она была указана по юлианскому стилю (грамоту «читали»), письмо поляка написано 8 января - по григорианскому стилю (в России было 29 декабря), к тому же, Я. Задзик был под Смоленском, а патриарх в Москве. Сообщение в письме Я. Задзика идентично тому, о чем говорится в грамоте из-под Смоленска: очевидно, Я. Задзик сообщил информацию о действиях Гермогена в Москве после ознакомления с грамотой Ф. Андронова и М. Салтыкова 29 декабря 1610 года.

За и против: переписка с рязанским архиепископом Феодоритом допускает факт существования грамот [11, с. 324]. Но В.Н. Козлякова, который сослался на данное свидетельство, эта переписка не убеждает: «Писал или не писал патриарх Гермоген при- зывные послания, - заключил исследователь именно его открытое неповиновение польсколитовским властям и их русским сторонникам обозначило возможный выход из тупика» [11, c. 324].

3a: ряд исследователей посчитали вопрос о грамотах Гермогена закрытым после публикации В.И. Корецким «Послания патриарха Гермогена» из Бельского летописца, обнаруженного им в составе сборника ГИМ [12, c. 476]. По мнению В.И. Корецкого, послание неверно размещено в летописце после информации о приходе ополчения К. Минина и Д. Пожарского под Москву (Гермоген к этому времени умер). Историк предположил, что это послание было обращено к первому ополчению, когда оно уже стояло под Москвой, и свидетельствует о связях патриарха с ополченцами, опровергая мнение Л.М. Сухотина о непричастности Гермогена к делу первого ополчения [12, с. $23 ; 24$, с. 324-338].

Против. Детально анализируя текст послания, мы не встречаем в нем какой-либо хронологической привязки к датам или событиям. Косвенно лишь одна фраза в начале может отнести его к ополчению: «...призывайте на помощь крепкую нашу заступницу... стояти против враговъ божьих и наших губителей, крепко уповая на Бога...». В остальном в тексте содержатся призывы к покаянию, обращению к Богу, «...отринуть от себя всякую ересь...», не читать «ересных», «гадательных», «душедьявольских» и «душегубительных» книг. Призыв в отношении книг доминирует в тексте и повторяется 5 раз. Никакого упоминания о католической вере или польсколитовских людях, о защите православной веры, на что были ориентированы ополчения, исходя из текста документов земской переписки, в грамоте нет. Это ставит под большое сомнение возможность считать данный текст посланием ополчению только на основании включения его в состав Бельского летописца составителями во второй половине XVII века.

Сравнение грамоты, обнаруженной В.И. Корецким, с воззваниями и посланиями Гермогена, ближайшими по времени составления (предшествующие 2 послания - февраль 1609 г., последнее из известных - конец августа 1611 г.), позволяет выявить ряд существенных отличий в построении текста. 
В первую очередь обращает на себя внимание то, что авторское начало в воззваниях выражено достаточно четко. Речь идет не только о прямом назывании себя: «Аз смиренный Ермоген, Божиею милостию патриарх Богом спасаемаго града Москвы и всеа Русии...» [3, № 169 (I), с. 286], «от патриарха Ермогена Московского и всеа Русии» [3, № 194 (II), с. 333 (в книге ошибочно с. 243)], «а яз должен за вас Бога молити» [3, № 194 (II), 334 (в книге ошибочно с. 244)], - но и об употреблении местоимений и форм глаголов первого лица единственного и множественного числа: «воспоминаю вам; и что много глаголю? не достает ми слово» [3, № 169 (I), с. 286]; «не благословляю» [3, № 194 (II), с. 333 (в книге ошибочно с. 243)], «мы чаем; мы радуемся и молим их» [3, № 169 (I), с. 287], «паки удивляемся [3, № 169 (II), с. 289]; «мы же с радостию и любовию восприимем вас и не будем о сем порицати вам» [3, № 169 (II), c. 291]. Если формы единственного числа указывают на автора напрямую, то употребление подобных форм множественного числа, соотносящихся в контексте с противопоставлением «свое - чужое», где позиция автора отождествляется с позицией православных христиан в целом, может быть отнесено к риторическим приемам скрытого речевого воздействия: «и о сих нам православным християном рыдание и плач, понеже братия наша суть и от нас изыдоша, но не с нами быша и изволиша, вместо радости, без конца мучение» [3, № 169 (II), с. 288], «проклят от святого собору и от нас» [3, № 194 (II), с. 333 (в книге ошибочно с. 243)]. По-видимому, сильное авторское начало можно отнести к определяющим характеристикам идиостиля Гермогена, поскольку, как отмечают исследователи, даже в житийных тестах патриарх, несколько противореча предшествующей агиографической традиции, ведет повествование от лица очевидца и участника событий [13, с. 280].

Другим важным отличием можно считать открытую эмоциональность текста воззваний, проявляющуюся в употреблении лексики эмоций (о понимании термина см.: [8, c. 23]), в достаточно пространных описаниях эмоциональных переживаний автора: «не достает ми слово, болезнует ми душа, болезнует сердце и вся внутренняя утерзается и вся со- стави мои содрагают, и плачуся, глаголю и рыданием вопию» [3, № 169 (I), с. 286-287]; «понеже во ум наш не вмещается сотвореная вами» [3, № 169 (I), с. 287]; «...и се во удивление приводит нас...» [3, № 169 (II), с. 288].

Еще одной отличительной чертой текстов воззваний Гермогена является наличие конкретных деталей - имен, названий, изложения событий и ссылок на документы: «И учали честь грамоту, писано ко всему миру из Литовских полков, от Руских людей: князя де Василья Шуйского одною Москвою выбрали на царство, а иные де городы того не ведают, и князь Василей де Шуйской нам на царстве нелюб...» [3, № 169 (II), с. 289]; «Да те бы вам грамоты с городов собрати к себе в Нижней Новгород да прислати в полки к бояром и атаманье» [3, № 194 (II), с. 333 (в книге ошибочно с. 243)].

Все названные особенности (субъективность, эмоциональность, конкретность повествования), сочетаясь с разнообразными приемами диалогизации текста: обращениями («Бывшим братиям нашим, ныне же и неведаем какъ и назвати вас...» [3, № 169 (I), с. 287]), риторическими вопросами («вы же сему ли ревнуете? Сего ли хощете? Сего ли жадаете?» [3, № 169 (I), с. 287], риторическими восклицаниями («помилуйте, помилуйте, братия и чада единородныя, своя душа и своя родителя отшедшая и живыя, отец своих и матерей, и жены своя, и чада, и сродники, други, возникните и вразумейте и возвратитеся!» [3, № 169 (I), с. 287), в целом позволяют создать информативно насыщенные, эмоционально заряженные и понятные для широких слоев населения тексты, призывающие к конкретным действиям.

Стиль грамоты, опубликованной В.И. Корецким, характеризуется отсутствием персонификации автора, подчеркнутой эмоциональности, конкретизации. Текст представляет собой выдержанную в строго назидательной тональности проповедь, лишенную конкретных деталей и призывов, автор которой скрывается за стройной мозаикой прецедентных текстов. Такое обилие отсылок к священным текстам скорее затрудняет восприятие текста, чем делает его доходчивым и ясным. И лишь повтор ключевых сочетаний «книги годателные», «книги душегубительные» позволяет определить его тему. 
Проведенный анализ сопоставим с наблюдением Н.Ф. Дробленковой: «Обличительные воззвания Гермогена, когда они предназначались для распространения через церковь, были близки по стилю к церковным проповедям. Агитационные же патриотические грамоты, рассылавшиеся по городам и обращенные к их жителям, сочетали книжную риторику с деловым стилем и просторечными оборотами, характерными для агитационной патриотической письменности городов 1608 1612 гг.» [10, с. 161-162].

Все это дает основание утверждать, что документ из Бельского летописца не является инициативным посланием к земскому ополчению периода гражданской войны.

В итоге мы приходим к следующему заключению. В настоящее время в исторической науке не известны самостоятельные тексты, которые можно было бы назвать инициативными грамотами, написанными от имени патриарха Гермогена к земству с целью организации вооруженного движения против польско-литовских интервентов.

Нет оснований не верить словам польских послов на переговорах 1615 г., которые держали перед собой грамоту с печатью патриарха и цитировали ее. Однако налицо хронологическое несоответствие между вероятностным фактором возможности написания грамот патриархом и цитируемой датой, имеющей расхождения также с упоминаемыми в польских же сочинениях сроками перехвата грамоты патриарха. Очевидно, правы были и русские послы, которые обличали предъявляемую грамоту как подделку. В противном случае, при рассылке патриархом грамот в середине или конце декабря 1610 г. протестное движение началось бы, как минимум, не в середине января 1611 г., а на месяц раньше, если устное благословение, привезенное нижегородцами 12 января 1611 г., возымело такое решающее действие.

Поиски грамот велись исследователями в двух направлениях в соответствии с двумя политическими центрами, откуда независимо развивалось движение: Переяславль Рязанский и Нижний Новгород. Земская переписка южных городов сохранилась крайне отрывочно, конкретных указаний на грамоты Гермогена нет. Переписка органов управления се- вернорусских городов, отложившаяся в Соликамском архиве, содержит только упоминания о грамотах патриарха, но ни в одном документе мы не находим даже краткого пересказа их содержания, как это происходило с остальными получаемыми на местах документами в этот период. Сопоставление последовательно передаваемой в грамотах информации с указанием на полученные в городах грамоты и отписки позволяет сделать наблюдение, что в Нижний Новгород 27 января действительно были доставлены грамоты от патриарха Гермогена, но это были воззвания, написанные не от его имени, а хорошо известные в науке грамота из-под Смоленска и окружная грамота московских жителей. Вторая иногда ошибочно принимаемая в земских учреждениях городов Севера и Сибири за грамоту Гермогена. В дальнейшем именно они, переписанные, пересылались из города в город, а факт их получения непосредственно от Гермогена сыграл ключевую роль в подъеме земского движения.

\section{ПРИМЕЧАНИЯ}

${ }^{1}$ Исследование выполнено при финансовой поддержке РФФИ, проект «Институты государственного управления в России в Смутное время начала XVII века» № 15-31-01202 (а2).

${ }^{2}$ Окончание пермской отписки отсутствует: лист № 4 не продолжает по тексту лист 3 и относится к какому-то чуть более позднему документу.

${ }^{3}$ Интересно, что, в отличие от сохранившегося в настоящее время в переплете архивного экземпляра, опубликованный вариант имеет третий лист, где указаны имена лиц, подписавших документ [1, № 323, c. 383-384].

\section{СПИСОК ЛИТЕРАТУРЫ}

1. Акты исторические, собранные и изданные Археографическою комиссиею : в 5 т. Т. 2 (15981613 гг.). - СПб. : Тип. Экспедиции заготовления гос. бумаг, $1841 .-482 \mathrm{c}$.

2. Акты, относящиеся к истории Западной России, собранные и изданные Археографическою комиссиею : в 5 т. Т. 4 (1588-1632). - СПб. : Тип. Эдуарда Праца, 1851. - 583 с.

3. Акты, собранные в библиотеках и архивах Российской империи археографическою экспедициею императорской академии наук : в 4 т. Т. 2. - 
СПб. : Тип. 2-го отд-ния Собственной Е.И.В. канцелярии, 1836. -392 с.

4. Вовина-Лебедева, В. Г. Ермоген / В. Г. Вовина-Лебедева // Православная энциклопедия. T. 18. - М. : Церковно-научный центр Русской Православной Церкви «Православная Энциклопедия», 2008. - С. 633-646

5. Володихин, Д. М. Патриарх Гермоген / Д. М. Володихин. - М. : Молодая гвардия, 2015. $300 \mathrm{c}$.

6. Выступление святейшего патриарха Кирилла на соборных слушаниях всемирного русского народного собора «Патриарх Гермоген, русское духовенство и церковь в служении отечеству» // Памятник патриарху Гермогену (Ермогену). Два века: от идеи до воплощения. - М. : РОФ СИООПП «Патриарху Гермогену», 2014. - С. 185-190.

7. Горбачев, П. О. Патриарх Гермоген и организация Первого земского ополчения (историографическая заметка) / П. О. Горбачев // Русский Сборник. - Брянск : Курсив, 2009. - С. 192-193.

8. Дмитриева, Е. Г. Функционирование глаголов эмоций в древнерусском апокрифическом тексте / Е. Г. Дмитриева // Вестник Волгоградского государственного университета. Серия 2, Языкознание. - 2012. - № 2 (16). - С. 23-28.

9. Дмитриевский, А. А. Арсений, Архиепископ елассонский и его вновь открытые исторические мемуары / А. А. Дмитриевский // Труды Киевской духовной академии. - Киев : Тип. Императорского ун-та, 1898. - Вып. 2. - Май (№ 5). - С. 88-129.

10. Дробленкова, Н. Ф. Гермоген / Н. Ф. Дробленкова // Словарь книжников и книжности Древней Руси. Вып. 2. Ч. 1. - Л. : Наука, 1988. - С. 153-163.

11. Козляков, В. Н. Смута в России. XVII век / В. Н. Козляков. - М. : Омега, 2007. - 528 с.

12. Корецкий, В. И. Послание патриарха Гермогена / В. И. Корецкий // Памятники культуры. Новые открытия. Письменность. Искусство. Археология: Ежегодник. 1975. - М. : Наука, 1976. - С. 22-26.

13. Литвина, Т. А. Образ автора в агиографических произведениях патриарха Гермогена / Т. А. Литвина // Вестник Челябинского государственного педагогического университета. - 2012. № 7. - С. 274-281.

14. Мельников-Печерский, П. И. Нижний Новгород и нижегородцы в Смутное время / П. И. Мельников-Печерский // Отечественные записки. 1843. - Т. ХХІХ. - Разд. II. - С. 17-18.

15. Отписка пермского воеводы И.И. Чемоданова и подьячего П. Филатова в Соликамск старостам и целовальникам с извещением о посылке ратных людей..., 10.03.1611 // Архив Санкт-Петербургского института истории Российской Академии наук (АСПб ИИ РАН). - Ф. 122. - ОП. 1. - Пер. І. № 343. -4 Л.
16. Отписка пермского воеводы И.И. Чемоданова и подьячего П. Филатова верхотурским воеводам С.С. Годунову и И.М. Плещееву о намерении выслать ратных людей на Верхотурье..., 13.03.1611// АСПб ИИРАН. -Ф. 122. -Оп. 1. -Пер. І. № 344. -2 л.

17. Отписка пермского воеводы И.И. Чемоданова и подьячего П. Филатова московскому патриарху Гермогену // АСПб ИИ РАН. - Ф. 122. - Оп. 1. Пер. I. - № 345. - 2 л.

18. Платонов, С. Ф. Очерки по истории Смутного времени в Московском государстве XVI-XVII вв. (опыт изучения общественного строя и сословных отношений в Смугное время) / С. Ф. Платонов. - Изд. 2-е. - СПб. : Тип. М.А. Александрова, 1910. - 642 с.

19. Платонов, С. Ф. О двух грамотах 1611 г. / С. Ф. Платонов // С. Ф. Платонов. Статьи по русской истории (1883-1912). - СПб. : Склад изд. у Я. Башмакова и К ${ }^{\circ}$ 1912. - С. 157-159.

20. Рыбалко, Н. В. Психологическая мотивация создания Подмосковного земского ополчения в начале 1611 г. / Н. В. Рыбалко// Локус: люди, общество, культуры, смыслы. - 2016. -№ 4. - С. 7-20.

21. Скрынников, Р. Г. Святители и власти / Р. Г. Скрынников. - Л. : Лениздат, 1990. - 349 с.

22. Соловьев, С. М. История России с древнейших времен / С. М. Соловьев // Соловьев С. М. Сочинения. В 18 кн. -М. : Голос, 1994. -Кн. IV. - Т. 8. -768 c.

23. Солодкин, Я. Г. «Междуусобная кровь пролилась». Очерки по истории публицистики и летописания в России конца XVI - первой трети XVII в. / Я. Г. Солодкин. - Нижний Вартовск : Изд-во Нижневарт. гуманит. ун-та, 2011. - 223 с.

24. Сухотин, Л. М. К вопросу о причастности патриарха Гермогена и князя Пожарского к делу первого ополчения / Л. М. Сухотин // Сборник статей в честь Матвея Кузьмича Любавского. - Пг. : Тип. Б.Д. Брукера, 1917. -С. 318-346.

25. Тюменцев, И. О. Сапежинцы и власти первого земского ополчения (по материалам русского архива Я. Сапеги 1610-1611 годов) / И. О. Тюменцев, Н. А. Тупикова // Вестник Волгоградского государственного университета. Серия 4, История. Регионоведение. Международные отношения. Вып. 12. -2007. - С. 143-159.

26. Флоря, Б. Н. Польско-литовская интервенция в России и русское общество / Б. Н. Флоря. М. : Индрик, 2005. -416 с.

27. Черепнин, Л. В. Русская хронология / Л. В. Черепнин. - М. : [б. и.], 1944. - 93 с.

\section{REFERENCES}

1. Akty istoricheskiye, sobrannye i izdannye Arkheograficheskoy komissieyu: v 5 t. T. 2 (1598- 
1613 gg.) [Historical Acts, Collected and Published by the Archaeographic Commission. In 5 vols. Vol. 2 (1598-1613)]. Saint Petersburg, Tip. Ekspeditsii zagotovleniya gos. bumag, 1841. $482 \mathrm{p}$.

2. Akty, otnosyashchiesya $k$ istorii zapadnoy Rossii, sobrannye i izdannye Arkheograficheskoy komissieyu: v 5 t. T. 4 (1588-1632 gg.) [Acts Relating to the History of Western Russia, Collected and Published by the Archaeographic Commission. In 5 vols. Vol. 4 (1588-1632)]. Saint Petersburg, Tip. Eduarda Pratsa, 1851.583 p.

3. Akty, sobrannye $v$ bibliotekakh $i$ archivakh Rossiyskoy imperii arkheograficheskoyu ekspeditsieyu imperatorskoy akademii nauk: $v 4 t$. T. 2 [Acts, Collected in Libraries and Archives of the Russian Empire by the Archaeographic Expedition of the Imperial Academy of Sciences. In 4 vols. Vol. 2]. Saint Petersburg, Tip. 2-go otd-niya Sobstvennoy E.I.V. kantselyarii, 1836. 392 p.

4. Vovina-Lebedeva V.G. Ermogen [Hermogenes]. Pravoslavnaya entsiklopediya. T. 18 [Orthodox Encyclopedia. Vol. 18]. Moscow, Tserkovno-nauchnyy tsentr Russkoy Pravoslavnoy Tserkvi "Orthodox Encyclopedia", 2008, pp. 633-646.

5. Volodikhin D.M. Patriarkh Germogen [Patriarch Hermogenes]. Moscow, Molodaya gvardiya Publ., 2015. 300 p.

6. Vystuplenie svyateyshego patriarkha Kirilla na sobornykh slushaniyakh vsemirnogo russkogo narodnogo sobora "Patriarkh Germogen, russkoe dukhovenstvo i tserkov v sluzhenii otechestvu" [Speech of his Holiness Patriarch Kirill at the Cathedral Hearings of the World Russian People's Cathedral "Patriarch Hermogen, the Russian Clergy and Church in the Service to the Fatherland"]. Pamyatnik patriarkhu Germogenu (Ermogenu). Dva veka: ot idei do voploshcheniya [A Monument to Patriarch Germogen (Hermogenes). Two Centuries: from Idea to its Implementation]. Moscow, ROF SIOOPP «Patriarkhu Germogenu», 2014, pp. 185-190.

7. Gorbachev P.O. Patriarkh Hermogen i organizatsiya Pervogo zemskogo opolcheniya (istoriograficheskaya zametka) [Patriarch Hermogenes and the organization of the First National Militia (Historiographical Notes)]. Russkiy Sbornik [Russian Collection]. Bryansk, Kursiv Publ., 2009, pp. 192-193.

8. Dmitrieva E.G. Funktsionirovanie glagolov emotsiy v drevnerusskom apokrificheskom tekste [Functioning of Verbs of Emotions in the Old Russian Apocryphal Texts]. Vestnik Volgogradskogo gosudarstvennogo universiteta. Seriya 2, Yazykoznanie [Science Journal of Volgograd State University. Linguistics], 2012, no. 2 (16), pp. 23-28.

9. Dmitrievskiy A.A. Arseniy, Arkhiepiskop Elassonskiy i ego vnov otkrytye istoricheskiye memuary [Arsenius, Archbishop lasansky and His
Newly Discovered Historical Memoirs]. Trudy Kievskoy dukhovnoy akademii [Proceedings of the Kiev Theological Academy]. Kiev, Tipografiya Imperatorskogo un-ta, 1898, vol. 2, no. 5, pp. 88-129.

10. Droblenkova N.F. Germogen [Hermogenes]. Slovar knizhnikov i knizhnosti Drevney Rusi [The Dictionary of Scribes and Booklore of Ancient Rus. Vol. 2. Part 1]. Leningrad, Nauka Publ., 1988, pp. 153-163.

11. Kozlyakov V.N. Smuta v Rossii. XVII vek [Turmoil in Russia. The 17th Century]. Moscow, Omega Publ., 2007. 528 p.

12. Koretskiy V.I. Poslanie patriarkha Hermogena [The message of Patriarch Germogen]. Pamyatniki kultury. Novye otkrytiya. Pismennost. Iskusstvo. Arkheologiya: Ezhegodnik. 1975 [Monuments of Culture. New Discoveries. Writing. Art. Archaeology: Annual 1975]. Moscow, Nauka Publ., 1976, pp. 22-26.

13. Litvina T.A. Obraz avtora $v$ agiograficheskikh proizvedeniyakh patriarkha Hermogena [The Author's Image in the Hagiographic Works of Patriarch Hermogenes]. Vestnik Chelyabinskogo gosudarstvennogo pedagogicheskogo universiteta, 2012, no. 7, pp. 274-281.

14. Melnikov-Pecherskiy P.I. Nizhniy Novgorod i nizhegorodtsy v Smutnoye vremya [Nizhniy Novgorod and its Inhabitants in the Time of Troubles]. Otechestvennye zapiski, 1843, vol. XXIX, part II, pp. 17-18.

15. Otpiska permskogo voevody I.I. Chemodanova i podyachego P. Filatova v Solikamsk starostam i tselovalnikam s izvescheniem o posylke ratnykh lyudey..., 10.03.1611 [Formal Reply of Perm Governor I. I. Chemodanov and Clerk P. Filatov to Chiefs and TaxCollector in Solikamsk with the Notice of Sending Military People... March 10, 1611]. Arkhiv SanktPeterburgskogo instituta istorii Rossiyskoy Akademii nauk (ASPb II RAN) [Archive of Saint Petersburg Institute of History, Russian Academy of Sciences], F. 122, Op. 1, Per. I, no. 343, p. 4.

16. Otpiska permskogo voevody I.I. Chemodanova i podyachego P. Filatova verkhoturskim voevodam S.S. Godunovu i I.M. Pleshcheevu o namerenii vyslat ratnykh ludey na Verkhoturye..., 13.03.1611 [Formal Reply of Perm Governor I. I. Chemodanov and Clerk P. Filatov to Verkhoturye Governors S. S. Godunov and I. M. Pleshcheev about the Intention to Send Military Men to Verkhoturye]. Arkhiv Sankt-Peterburgskogo instituta istorii Rossiyskoy Akademii nauk (ASPb II $R A N$ ) [Archive of Saint Petersburg Institute of History, Russian Academy of Sciences], F. 122, Op. 1, Per. I, no. 344 , p. 2 .

17. Otpiska permskogo voevody I.I. Chemodanova i podyachego P. Filatova moskovskomu patriarkhu Hermogenu [Formal Reply of Perm Governor I. I. Chemodanov and clerk P. Filatov to Moscow Patriarch Hermogenes]. Arkhiv Sankt-Peterburgskogo 
instituta istorii Rossiyskoy Akademii nauk (ASPb II $R A N)$ [Archive of Saint Petersburg Institute of History, Russian Academy of Sciences], F. 122, Op. 1, Per. I, no. 345 , p. 2 .

18. Platonov S.F. Ocherki po istorii Smutnogo vremeni v Moskovskom gosudarstve XVI-XVII vv. (opyt izucheniya obschestvennogo stroya $i$ soslovhykh otnosheniy $v$ Smutnoe vremya) [Essays on the History of the Time of Troubles in the Moscow State in the $16^{\text {th }}-17^{\text {th }}$ Centuries (Experience of Studying Social Structure and Class Relations in the Time of Troubles)]. Saint Petersburg, Tip. M.A. Aleksandrova, 1910. $642 \mathrm{p}$.

19. Platonov S.F. O dvukh gramotakh 1611 g. [About Two Letters of 1611]. S.F. Platonov. Statyi po russkoy istorii (1883-1912) [S.F. Platonov. Articles on Russian History (1883-1912)]. Saint Petersburg, Sklad izd. u Ya. Bashmakova i Kº, 1912, pp. 157-159.

20. Rybalko N.V. Psikhologicheskaya motivatsiya sozdaniya Podmoskovnogo zemskogo opolcheniya $\mathrm{v}$ nachale $1611 \mathrm{~g}$. [Psychological Motivation for Creating National Movement of Moscow State in Early 1611]. Lokus: lyudi, obshchestvo, kultury, smysly [Locus: people, society, culture, meanings], 2016, no. 4, pp. 7-20.

21. Skrynnikov R.G. Svyatiteli i vlasti [Saints and Authorities]. Leningrad, Lenizdat Publ., 1990. $349 \mathrm{p}$.

22. Solovyev S.M. Istoriya Rossii s drevneyshikh vremen [History of Russia from ancient times]. Solovyev S.M. Sochineniya. V 18 kn. Kn. 4 [Solovyev S.M. Works. In 18 books. Book 4]. Moscow, Golos Publ., 1994, vol. 8. 768 p.
23. Solodkin Ya.G. "Mezhduusobnaya krov prolilas». Ocherki po istorii publitsistiki $i$ letopisaniya $v$ Rossii kontsa XVI - pervoy treti XVII v. ["Internecine Blood Was Shed". Essays on the History of Journalism and Chronicle Writing in Russia in the late $16^{\text {th }}$ - First Third of the $17^{\text {th }}$ Century]. Nizhniy Vartovsk, Izd-vo Niznevart. gumanit. un-ta, 2011. 223 p.

24. Sukhotin L.M. K voprosu o prichastnosti patriarkha Germogena i knyazya Pozharskogo k delu pervogo opolcheniya [To the Question about the Involvement of Patriarch Hermogenes and Prince Pozharsky to the Case of the First Militia]. Sbornik statey v chest Matveya Kuzmicha Lyubavskogo [A Collection of Articles in Honor of Matthew Kuzmich Lubawskie]. Prague, Tip. B.D. Brukera, 1917, pp. 318-346.

25. Tyumentsev I.O., Tupikova N.A. Sapezhintsy i vlasti pervogo zemskogo opolcheniya (po materialam russkogo arkhiva Ya. Sapegi 1610-1611 godov) [J. Sapieha's Followers and the Authorities of the First National Militia (on Materials of the Russian Archive of J. Sapieha. 1610-1611)]. Vestnik Volgogradskogo gosudarstvennogo universiteta. Seriya 4, Istoriya. Regionovedeniye. Mezhdunarodnye otnosheniya [Science Journal of Volgograd State University. History. Regional Studies. International Relations], 2007, no. 12, pp. 143-159.

26. Florya B.N. Polsko-litovskaya interventsiya $v$ Rossii i russkoe obshchestvo [The Polish-Lithuanian Intervention in Russia and Russian Society]. Moscow, Indrik Publ., 2005. 416 p.

27. Cherepnin L.V. Russkaya khronologiya [Russian Chronology]. Moscow, 1944. 93 p.

\section{Information about the Authors}

Nataliya V. Rybalko, Candidate of Sciences (History), Associate Professor, Department of History of Russia, Volgograd State University, Prosp. Universitetsky, 100, 400062 Volgograd, Russian Federation, natalia.rybalko@volsu.ru, rybalko_n@mail.ru,http://orcid.org/0000-0002-5141-0902.

Evgeniya G. Dmitrieva, Candidate of Sciences (Philology), Associate Professor, Department of Russian Language and Documentation Studies, Volgograd State University, Prosp. Universitetsky, 100, 400062 Volgograd, Russian Federation, eg_dmitrieva@volsu.ru, http://orcid.org/0000-0001-5117-5677.

Elena S. Maleeva, Candidate of Sciences (Philology), Associate Professor, Lecturer, Vienna University of Applied Sciences, Wohlmutstraße 22, 1020 Vienna, Austria, elena.maleeva@fh-vie.ac.at, http://orcid.org/0000-0002-8437-8339.

\section{Информация об авторах}

Наталия Владимировна Рыбалко, кандидат исторических наук, доцент кафедры истории России, Волгоградский государственный университет, просп. Университетский, 100, 400062 г. Волгоград, Российская Федерация, natalia.rybalko@volsu.ru, rybalko_n@mail.ru, http://orcid.org/00000002-5141-0902. 


\section{ИСТОРИЯ РОССИИ}

Евгения Геннадьевна Дмитриева, кандидат филологических наук, доцент кафедры русского языка и документалистики, Волгоградский государственный университет, просп. Университетский, 100, 400062 г. Волгоград, Российская Федерация, eg_dmitrieva@volsu.ru, http://orcid.org/ 0000-0001-5117-5677.

Елена Сергеевна Малеева, кандидат филологических наук, доцент, преподаватель, Венский университет прикладных наук, Wohlmutstraße 22, 1020 г. Вена, Австрия, elena.maleeva@fhvie.ac.at, http://orcid.org/0000-0002-8437-8339. 